\title{
Multi-phenyl structured aromatic hydrocarbon polymer
}

\author{
M. A. Hossain ${ }^{1 *}$, Morium ${ }^{1}$, M. Elias ${ }^{1}$, M. M. $\operatorname{Rahman}^{1}$, M. M. Rahman ${ }^{2}$, M. S. Ali ${ }^{1}$ and M. A. $\operatorname{Razzak}^{1}$ \\ ${ }^{1}$ Department of Chemistry, Jagannath University, Dhaka-1100, Bangladesh \\ ${ }^{2}$ Department of Polymer, Bangladesh Council of Scientific and Industrial Research (BCSIR), Dhaka 1205, Bangladesh
}

Received: 21 July 2019

Revised: 25 August 2019

Accepted: 11 November 2019

DOI: https://doi.org/10.3329/bjsir.v55i2.47634

\begin{abstract}
Multi-phenyl structured random polymer was synthesized via condensation polymerization reaction by applying different monomer ratios and characterized by various spectroscopic methods (FT-IR, ${ }^{1} \mathrm{H}$ NMR). The prepared polymers showed good thermooxidative stability up to $400{ }^{\circ} \mathrm{C}$. The surface morphology was studied by FESEM that showed the good linkage among the polymer chains. The EDS data of poly(fluorenylene ether ketone), PFEK; demonstrated that all the monomers participated in the copolymerization reaction. Inherent viscosity values of the polymers were obtained in the range of $0.76 \sim 1.12 \mathrm{dL} \mathrm{g}^{-1}$. The polymers' yield was within $85 \sim 90 \%$. The obtained results indicate that the multi-phenyl structured polymer will be the good candidates to prepare the effective aromatic hydrocarbon polymer electrolyte membrane.
\end{abstract}

Keywords: Multi-phenyl; Aromatic hydrocarbon polymer; Condensation polymerization; Thermooxidative stability; Inherent viscosity

\section{Introduction}

The rapid increase of carbon dioxide is the key to the ruthless impact on the Earth's climate, particularly global warming. Therefore, it is now essentially a great demand to develop an effective alternative energy source which emits zero greenhouse gases. Fuel cell is such kind of energy source that generates electrical energy with no emission of greenhouse gas. Fuel cells represent a promising class of power sources with high energy density and low pollution though their cost and durability deter their extensive use. Perfluorosulfonic acid polymers (such as DuPont ${ }^{\mathrm{TM}}$ Nafion $^{\circledR}$, Flemion ${ }^{\circledR}$ etc.) are the most effective polymer electrolyte membranes developed for high proton conductivity. They are physically, chemically and thermally stable but their applicability is hindered by limited operational temperature ranges $\left(0 \sim 80{ }^{\circ} \mathrm{C}\right)$, high production and processing costs, high fuel permeability, and environmental incompatibility. At low temperatures, there is a possibility of $\mathrm{CO}$ poisoning of $\mathrm{Pt}$ and $\mathrm{Pt}$-based electrocatalysts (Savadogo, 1998; Kreuer, 2001; Carreta et. al, 2000). Nafion is the fluorinated non-aromatic polymer electrolyte membrane. The performance of nafion is extremely high. However, it is very costly and also durability is poor (Singh and Hay, 1992). Mitsuru Ueda and coworkers reported on the proton exchange membrane which was fluorinated material (Nakabayashi et al., 2008). Fluorinated compounds are very costly as well as hostile to the environment. They inserted sulfonic acid groups in the polymer backbone to make the membrane which were chemically and mechanically less durable. James E. McGrath and his coworkers also reported the membrane similar to the previous one (Roy et al., 2009). The cost and performance limitations of current perfluorinated polymer electrolyte (proton exchange membranes, PEM), such as Nafion have hindered large-scale commercialization and market penetration of polymer electrolyte membrane fuel cells (PEMFC) in mobile and stationary systems. 
As the fluorinated polymers are not friendly to the environment, their ordinary disposal system may bring bad impact on our living systems. This has sparked worldwide research efforts to design alternative polymer electrolyte membrane (PEM) materials with high ionic conductivity, thermal stability to allow operation over $100{ }^{\circ} \mathrm{C}$, chemical stability to a strong acid, good processability, and excellent barrier properties to fuels (e.g. methanol, oxygen, etc.) (Savadogo, 1998; Mauritz and Moore, 2004). One common approach has been to sulfonate existing thermoplastics such as polystyrene (Ding et al., 2001; Roziere and Jones, 2003), poly (ether ketone)s (Zaidi 2000; Jones and Roziere, 2001) and poly (ether sulfone)s (Nolte et al., 1993; Wang et al., 2002). This has generated mostly PEM's with lower costs and improved thermal stability, but generally lower ionic conductivities at comparable ion exchange capacities than Nafion (Kreuer, 2001) and many of these thermoplastics-based PEMs are more susceptible to oxidative or acid-catalyzed degradation than Nafion (Hubner and Roduner, 1999). Employing a purely aromatic polymer, such as poly (phenylenes), provides a route to potentially improve the thermochemical stability of PEMs due to their inherent thermochemical stability. High molecular weights are necessary for these aromatic polymers to ensure polymer chain entanglements that are responsible for producing physically robust PEM films. A physically robust film is one essential characteristic of a membrane electrode assembly in order to survive with a PEMFC environment. Sulfonated aromatic polymers are relatively high proton conductive $(10-200 \mathrm{mS} / \mathrm{cm})$ and have good PEM characteristics (Kobayashi et al., 1998). However, achieving high molecular weights based upon this class of polymer is dependent on the pendent group of the aryl halide monomer (Hagberg et al., 2004), which limits sulfonation and broad functionalization. Tanaka et al. (2011) also reported on aromatic hydrocarbon polymers to fabricate electrolyte membranes which contain only hydrophilic units that may reduce the durability of the membranes (Tanaka et al., 2010; Tanaka et al., 2011). Additionally, most of the polymers possess the keto group $(-\mathrm{C}=\mathrm{O})$ which can make the polymer crystalline (Singh and Hay, 1992). Hence, the aim of this present work is to prepare non-fluorinated aromatic polymer containing only pendant phenyl groups as they are cost effective and highly durable. Polymers with pendant phenyl groups are both physically and chemically strong as well as insertion of a good number of ionic functional groups. We have designed the polymer structure in such a way - it may hold both the hydrophilic and hydrophobic units as well as balancing the monomers' mole ratio in the both units so that after membranes' preparation which will obviously improve the strength of the membranes.

The present study focuses on the development of thermally stable multi-phenyl structured aromatic hydrocarbon polymers which are used as the platform to prepare polymer electrolyte membrane for fuel cell. Our aim is to prepare nonfluorinated poly (phenylene) polymer that provides a very promising solution to achieving PEMs with high molecular weights and overcome the limitations of sulfonation and broad functionalization. Here, we report the fully aromatic polymers with new polymer backbone those are easily processable as well as thermally and chemicallyrobust. The prepared new multi-phenyl structured random polymers through condensation polymerization will be able to provide 2-6 ionic functional groups, hence high ion conductivities, which is the vital characteristic of PEM materials.

\section{Materials and methods}

Bis (4-fluorophenyl) sulfone (Sigma-Aldrich, Germany, 99\%),9,9-bis (4-hydroxyphenyl) fluorine (TCI Japan, 97\%), 2,4-dihydroxyphenyl benzophenone (TCI Japan, 98\%),4, 4-diflurobenzophenone (Sigma-Aldrich, Germany, 99\%), 2,2-bis ( 4-hydroxyphenyl) propane (TCI Japan, 99\%), bis- (4-chlorophenyl) sulfone (TCI Japan, 99\%),4,4-biphenol (TCI Japan 99\%), anhydrous potassium carbonate (Merck, Germany, 99\%) were purchased and used as received. Commercially available solvents $-N, N$-dimethyl acetamide, toluene, dichloromethane, methanol, chloroform, acetone- were used without further purification.

\section{Preparation of multi-phenyl structured polymer}

\section{General procedure}

A typical condensation polymerization procedure is as follows: Polymerization was carried out in a $100 \mathrm{~mL}$ three-neck round bottomed flask fitted with a Dean-Stark trap, a condenser, a nitrogen inlet/outlet and a magnetic stirrer. The flask was charged with monomers, potassium carbonate, tolueneand $N, N$-dimethyl acetamide. The mixture was refluxed for $6 \mathrm{~h}$ at $135^{\circ} \mathrm{C}$ under nitrogen atmosphere with the Dean-Stark trap. The reaction mixture was dehydrated and toluene was removed 


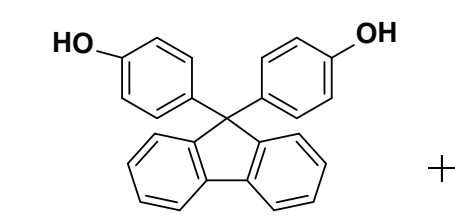

A

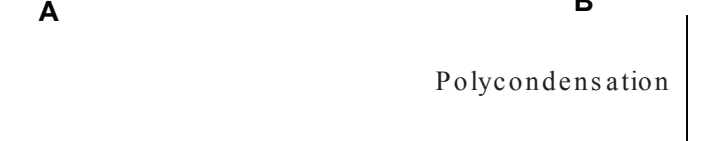

DMAc-Toluene $\mathrm{K}_{2} \mathrm{CO}_{3}$ Reflux

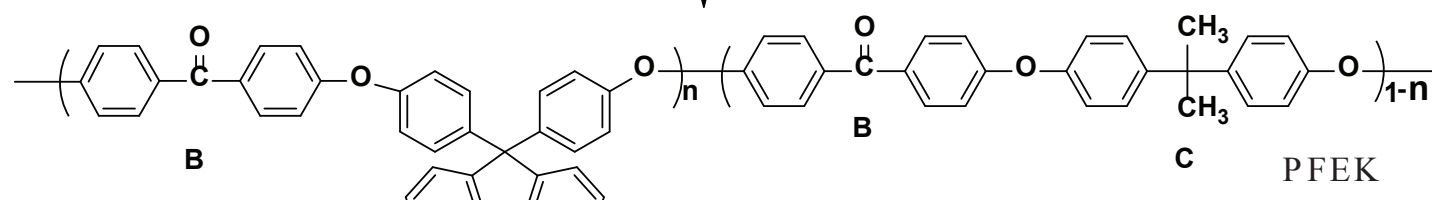

$\mathrm{n}=0.2$

A

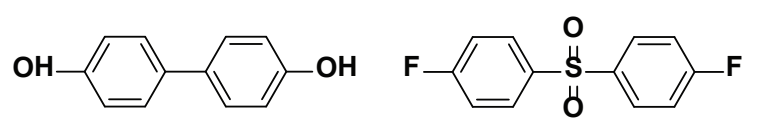

D

E<smiles>O=C(c1ccc(O)cc1)c1ccc(O)cc1</smiles>

$\mathbf{F}$<smiles>O=S(=O)(c1ccc(Cl)cc1)c1ccc(Cl)cc1</smiles>

G

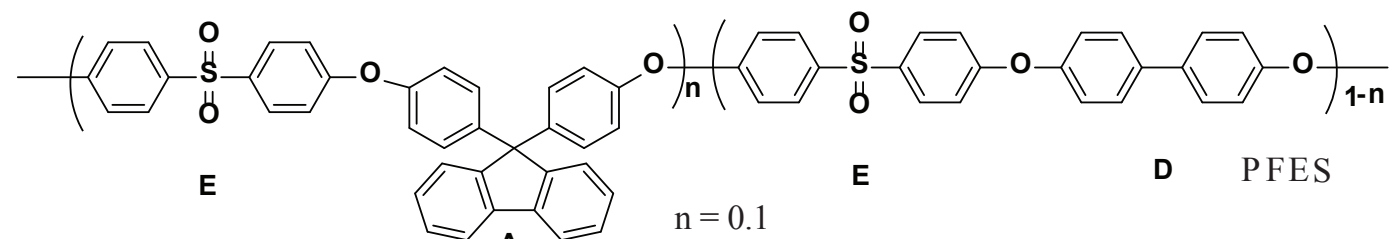<smiles>CC(C)(C)c1ccc(Oc2ccc(C(=O)c3ccc(Oc4ccc(S(=O)(=O)c5ccc(Oc6ccc(C(C)(C)C(C)(C)C)cc6)cc5)cc4)cc3)cc2)cc1</smiles>

E

$\mathrm{n}=0.25$

C PEKS

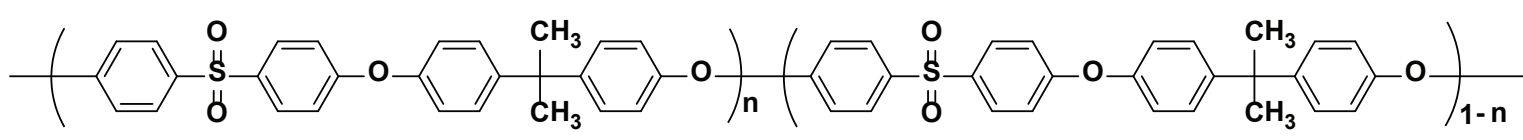

G

C

$\mathrm{n}=0.5$

E

C

PES

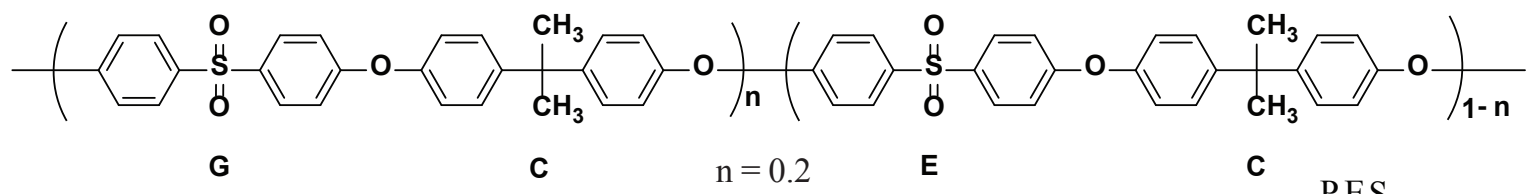

PES

Scheme 1. Preparation of multi-phenyl structured aromatic hydrocarbon polymer 
dropwise. It was gradually heated to $165{ }^{\circ} \mathrm{C}$ and kept at this temperature for $2 \mathrm{~h}$ until a highly viscous solution was obtained. The reaction mixture was then cooled to room temperature. Then the mixture was poured into the mixture of methanol $(250 \mathrm{ml})$ and water $(250 \mathrm{ml})$. A white fibrous polymer was collected by filtration. The crude polymer was dried for $10 \mathrm{~min}$ and then dissolved in dichloromethane. The purified polymer was achieved by re-precipitation from dichloromethane solution in hot water and collected by filtration.It was dried in a vacuum oven at $80{ }^{\circ} \mathrm{C}$ for $24 \mathrm{~h}$.

Preparation of poly (fluorenylene ether sulfone) containing biphenyl moiety, (PFES)

The flask was charged with bis(4-fluorophenyl)sulfone (2.53 g, $9.83 \mathrm{mmol})$, 9,9-bis(4-hydroxyphenyl)fluorene (0.36 g,0.98 mmol), 4,4 biphenol (1.83g,8.85 mmol ), potassium carbonate $(1.73 \mathrm{~g}, 12.29 \mathrm{mmol})$, toluene (11.0 $\mathrm{mL})$ and $N, N$-dimethyl acetamide $(14.0 \mathrm{~mL})$. The yield of the polymer was $85 \% .{ }^{1} \mathrm{H}$ NMR $\left(400 \mathrm{MHz} \mathrm{CDCl}_{3}\right), \delta=$ ppm: $8.00 \sim 7.77(\mathrm{~m}, 10 \mathrm{H}), 7.65 \sim 7.55(\mathrm{~m}, 8 \mathrm{H}), 7.45 \sim 7.20$ $(\mathrm{m}, 2 \mathrm{H}), 7.20 \sim 6.85(\mathrm{~m}, 20 \mathrm{H})$. FT-IR: 3022 (aromatic C-H), 1586 1487 (aromatic C=C), $1323 \& 1151$ (O-S-O), 1241(aryl ether) $\mathrm{cm}^{-1}$.

Preparation of poly (fluorenylene ether ketone) containing bisphenol A moiety, (PFEK)

To a 100 mL flask,4,4-Difluorobenzophenone (2.53,11.457mmol),9,9-Bis(4-hydroxyphenyl) fluorine $(0.8278 \mathrm{~g}, 2.292 \mathrm{mmol})$, Bisphenol-A $\quad(2.11 \mathrm{~g}, 9.166 \mathrm{mmol})$, potassium carbonate $(2.02 \mathrm{~g}, 14.322 \mathrm{mmol})$, toluene $(11.0 \mathrm{~mL})$ $\& N, N$-dimethyl acetamide $(14.0 \mathrm{~mL})$ were mixed.The yield of the polymer was $90 \% .{ }^{1} \mathrm{H}$ NMR $\left(400 \mathrm{MHz}, \mathrm{CDCl}_{3}\right), \delta=$ ppm: $7.88 \sim 7.70(\mathrm{~m}, 10 \mathrm{H}), 7.50 \sim 7.20(\mathrm{~m}, 12 \mathrm{H}), 7.14 \sim 6.90$ $(\mathrm{m}, 18 \mathrm{H}), 1.75$ (s, 6H). FT-IR: 3012 (aromatic C-H), 2950 \& 1417 (Me-C-H), $1650(\mathrm{C}=\mathrm{O}), 1592 \sim 1498$ (aromatic $\mathrm{C}=\mathrm{C}$ ), 1238(aryl ether) $\mathrm{cm}^{-1}$.

Preparation of (poly ether sulfone ketone) containing bisphenol A moiety, (PEKS)

The flask was charged with bis(4-flurophenyl) sulfone (2.53g,9.83mmol), 2, 2-bis (4-hydroxyphenyl) propane $(1.70 \mathrm{~g}, 7.37 \mathrm{mmol}), 4,4-$ dihydroxybenzophenone $(0.54 \mathrm{~g}$,

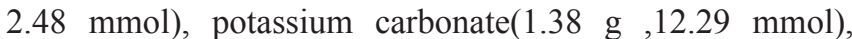
toluene $(8.0 \mathrm{~mL})$ and $N, N$-dimethyl acetamide $(10.0 \mathrm{~mL})$. The yield of the polymer was $85 \% .{ }^{1} \mathrm{H}$ NMR $(400 \mathrm{MHz}$, $\left.\mathrm{CDCl}_{3}\right), \delta=$ ppm: 8.00 7.80 (m, 10H), 7.32 $7.22(\mathrm{~m}, 6 \mathrm{H})$, 7.20 6.95 (m, 16H), $1.72(\mathrm{~s}, 6 \mathrm{H})$. FT-IR: 3021 (aromatic
C-H), 1586 1489 (aromatic $\mathrm{C}=\mathrm{C}$ ), 1244 (aryl ether), 1151 (O-S-O) $\mathrm{cm}^{-1}$.

Preparation of poly (ether sulfone) containing bisphenol $A$ moiety, (PES)

To a $100 \mathrm{~mL}$ flask, bisphenol-A (3.53 g, $15.33 \mathrm{mmol})$, bis(4-chlorophenyl)sulfone (2.25 g, $7.67 \mathrm{mmol})$, bis-(4-flurophenyl)sulfone $(1.97 \mathrm{~g}, 7.67 \mathrm{mmol})$, potassium carbonate $(2.70 \mathrm{~g}, 19.16 \mathrm{mmol})$,toluene $(10.0 \mathrm{~mL}) \& N, N$ dimethyl acetamide $(15.0 \mathrm{~mL})$. The yield of the polymer was 90\%. ${ }^{1} \mathrm{H}$ NMR (400 MHz, $\mathrm{CDCl}_{3}$ ), $\delta=$ ppm: 7.92 7.82 (d, $8 \mathrm{H}), 7.28 \sim 7.21(\mathrm{~m}, 8 \mathrm{H}), 7.08 \sim 6.91(\mathrm{dd}, 16 \mathrm{H}), 1.71(\mathrm{~s}, 12 \mathrm{H})$. FT-IR: 3030 (aromatic C-H), 2950 (Me-C-H), 1586 1489 (aromatic $\mathrm{C}=\mathrm{C}$ ), 1320 \& 1150 (O-S-O), 1244(aryl ether) $\mathrm{cm}^{-1}$.

\section{Characterization of polymer}

The copolymer structure was identified by Fourier transform infrared (FT-IR) spectroscopy using a SHIMADZU IR Tracer-100 infrared spectrometer within the range of $4000-400 \mathrm{~cm}^{-1} .{ }^{1} \mathrm{H}$ NMR spectra of the random polymers were recorded on a Bruker DRX (400 $\mathrm{MHz})$ spectrometer using deuterated chloroform $\left(\mathrm{CDCl}_{3}\right)$ as a solvent and tetramethylsilane (TMS) as an internal standard. Thermogravimetric analysis was carried out using a Shimadzu TGA-50H analyzer at a heating rate of $20{ }^{\circ} \mathrm{C}$ $\min ^{-1}$ in an alumina pan. The morphology of a polymer was investigated with a Field Emission Scanning Electron Microscope (FESEM, JEOL JSM-7600F). Point and shoot analyses were applied to determine the presence of elements in the polymer sample by Energy-disperse X-ray spectroscopy (EDS). Inherent viscosity of the polymers was determined at a concentration of $0.5 \mathrm{~g} / \mathrm{dL}$ in dimethyl acetamide (DMAc) at $30{ }^{\circ} \mathrm{C}$ with an Ostwald capillary viscometer.

\section{Results and discussion}

Different type of polymers (Scheme 1; PFES, PFEK, PEKS and PES) containing various structural moieties were prepared to make better proton exchange membrane's material. We have confirmed the polymer structure by ${ }^{1} \mathrm{H}$ NMR (Fig. 1). All of the phenyl protons' peaks were observed within the range of $8.00 \sim 6.85 \mathrm{ppm}$. The value of chemical shift for methyl protons was found in $1.71 \mathrm{ppm}$. The NMR data showed the good resemblance with the previous reports (Tanaka et al., 2010; Tanaka et al., 2011; Pan et al., 2010). 
We have also characterized the polymer structure by means of FT-IR study (Fig. 2). These data also afforded the good support on the successfully preparation of polymers. The

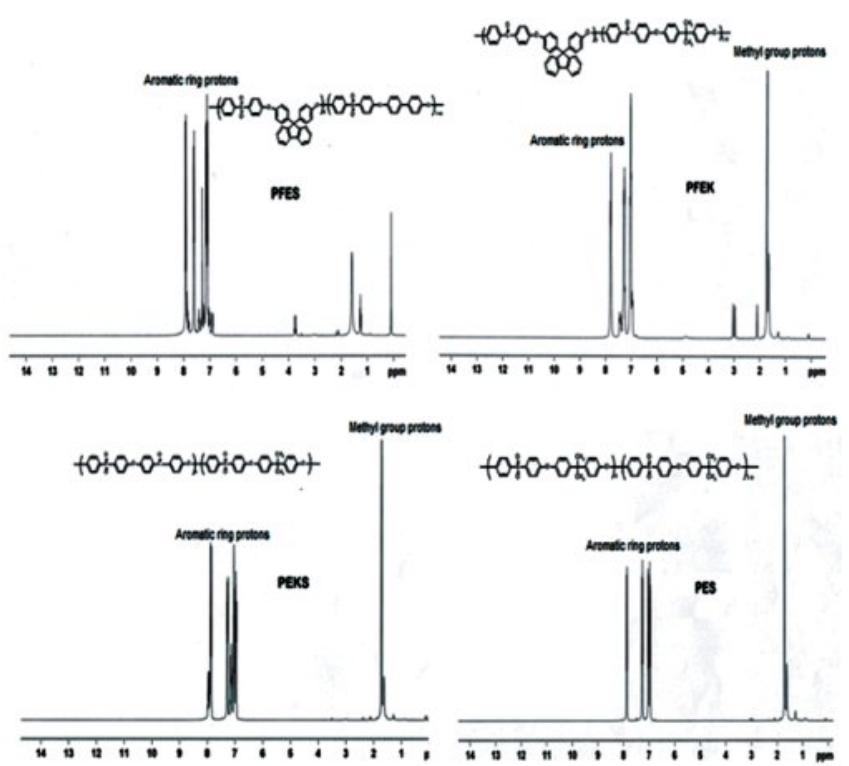

Fig. 1. ${ }^{1} \mathrm{H}$ NMR Spectra ofthe synthesized polymers (PFES, PFEK, PEKS and PES)
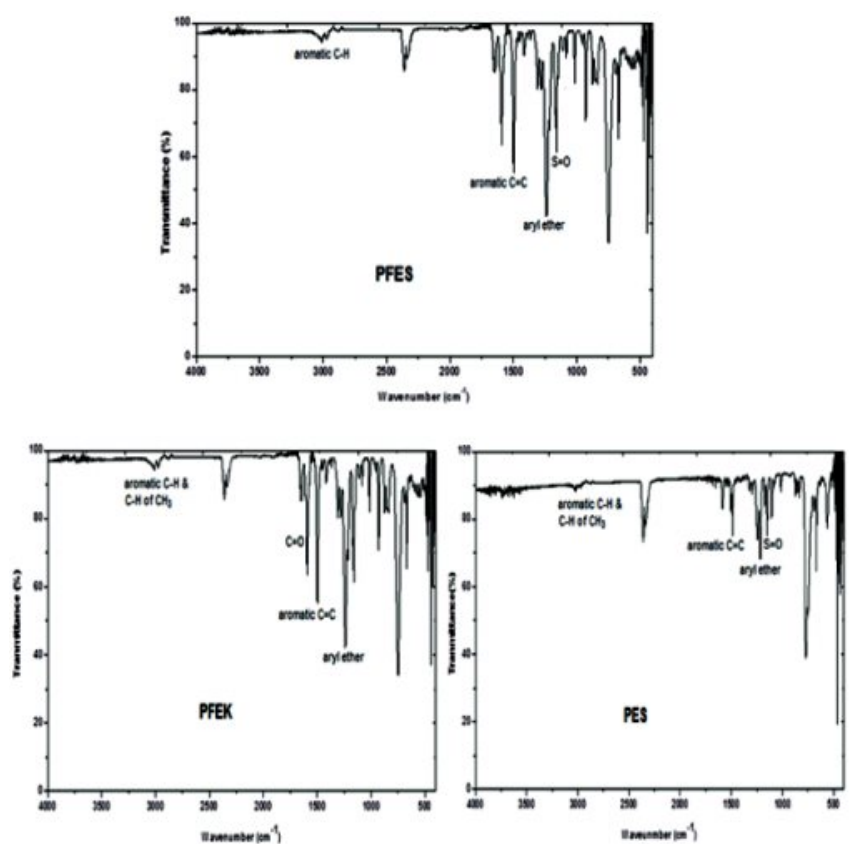

Fig. 2. FT-IR spectra of the synthesized polymers (PFES, PFEK and PES)

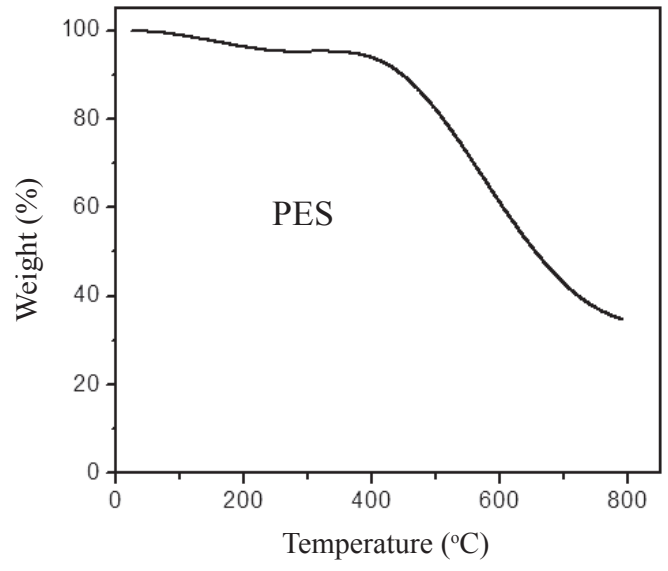

Fig. 3. Thermogravimetric analysis of the poly (ether sulfone) copolymer containing bisphenol A moiety

IR-stretching bands were detected for the aromatic $\mathrm{C}-\mathrm{H}$ and methyl C-Hin the region of $3100 \sim 2900 \mathrm{~cm}^{-1}$. The aromatic $\mathrm{C}=\mathrm{C}$, aryl ether as well as $\mathrm{S}=\mathrm{O}$ stretching bands were observed in 1586 1489, 1244 and $1150 \mathrm{~cm}^{-1}$ respectively. The FT-IR data of the prepared polymers were verified with the Zhou et al. (2009) report.

The thermooxidative stability of the poly ether sulfone polymer was studied by thermogravimetric analysis. The synthesized copolymer displayed sharp thermal stablity up to $400{ }^{\circ} \mathrm{C}$ (Fig. 3). The weight loss region above $400{ }^{\circ} \mathrm{C}$ is

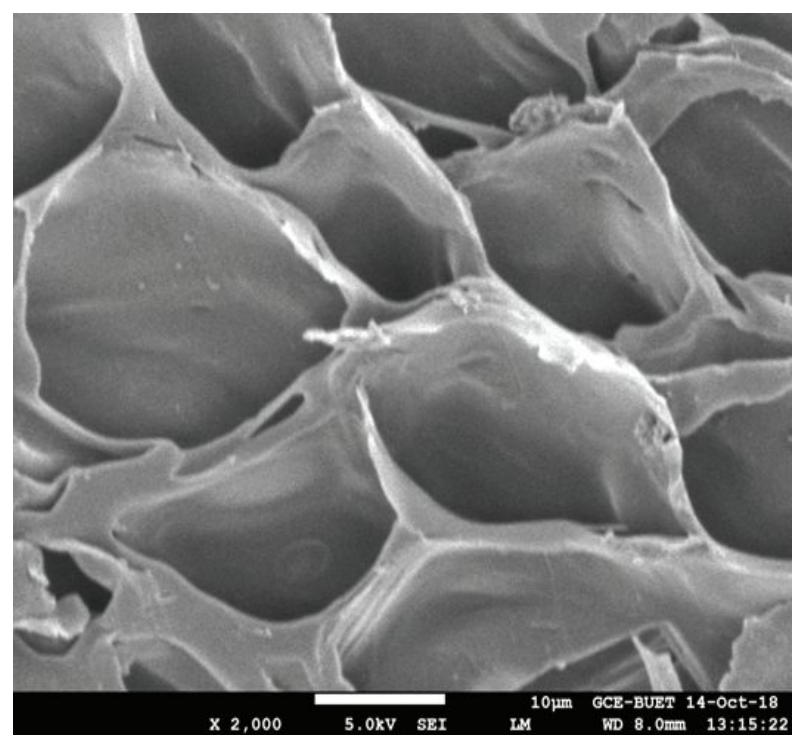

Fig. 4. Scanning electron microscopy (SEM) images of synthesized poly (fluorenylene ether ketone) containing bisphenol A moiety, (PFEK) 


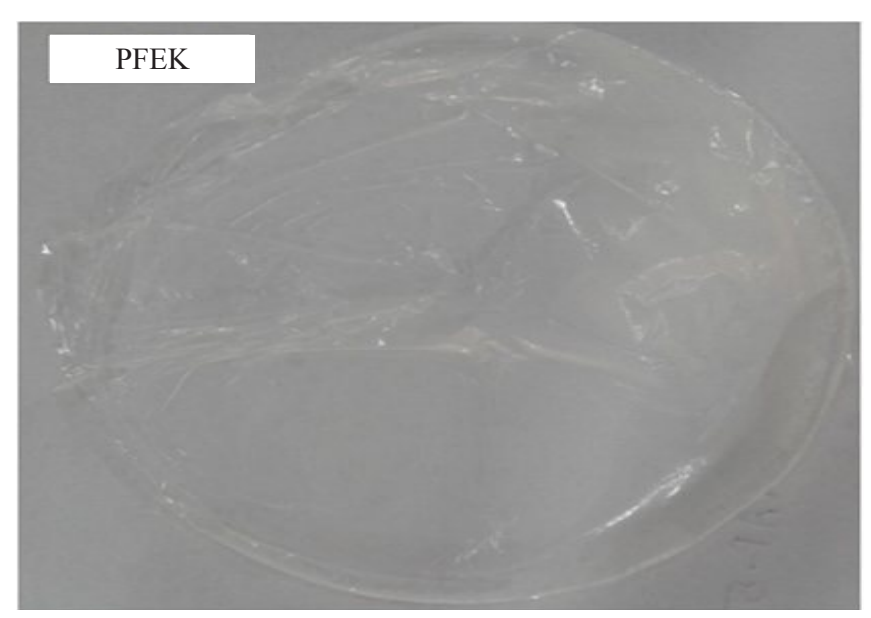

Fig. 5. Flim of synthesized poly (fluorenylene ether ketone) containing bisphenol A moiety, (PFEK) possible due to polymer backbone (ether linkage) degradation (Roy et al., 2009; Wang et al., 2012; Pan et al., 2010). It is also expected the similar thermal stability of the other prepared polymers.

Inherent viscosity $\left(\eta_{\text {inh }}\right)$ values of the polymers were in the range of $0.76 \sim 1.12 \mathrm{dl} \mathrm{g}^{-1}$ at a concentration of $0.5 \mathrm{~g} / \mathrm{dl}$ in dimethyl acetamide (DMAc) at $30{ }^{\circ} \mathrm{C}$ which indicate that polymers with reasonably high molecular weight were successfully obtained (Nakabayashi et al., 2010; Nakabayashi et al., 2008; Nakabayashi et al., 2008; Wang et al., 2012). The probable number average molecular weight $(\mathrm{Mn})$ could be around $10 \times 10^{4} \mathrm{~g} \mathrm{~mol}^{-1}$. Poly ether sulfones (PESs) were prepared using both chloro- and fluoro-monomers via altering the mole ratio (Scheme 1). The viscosity results showed that fluoro monomer gave better polymer.

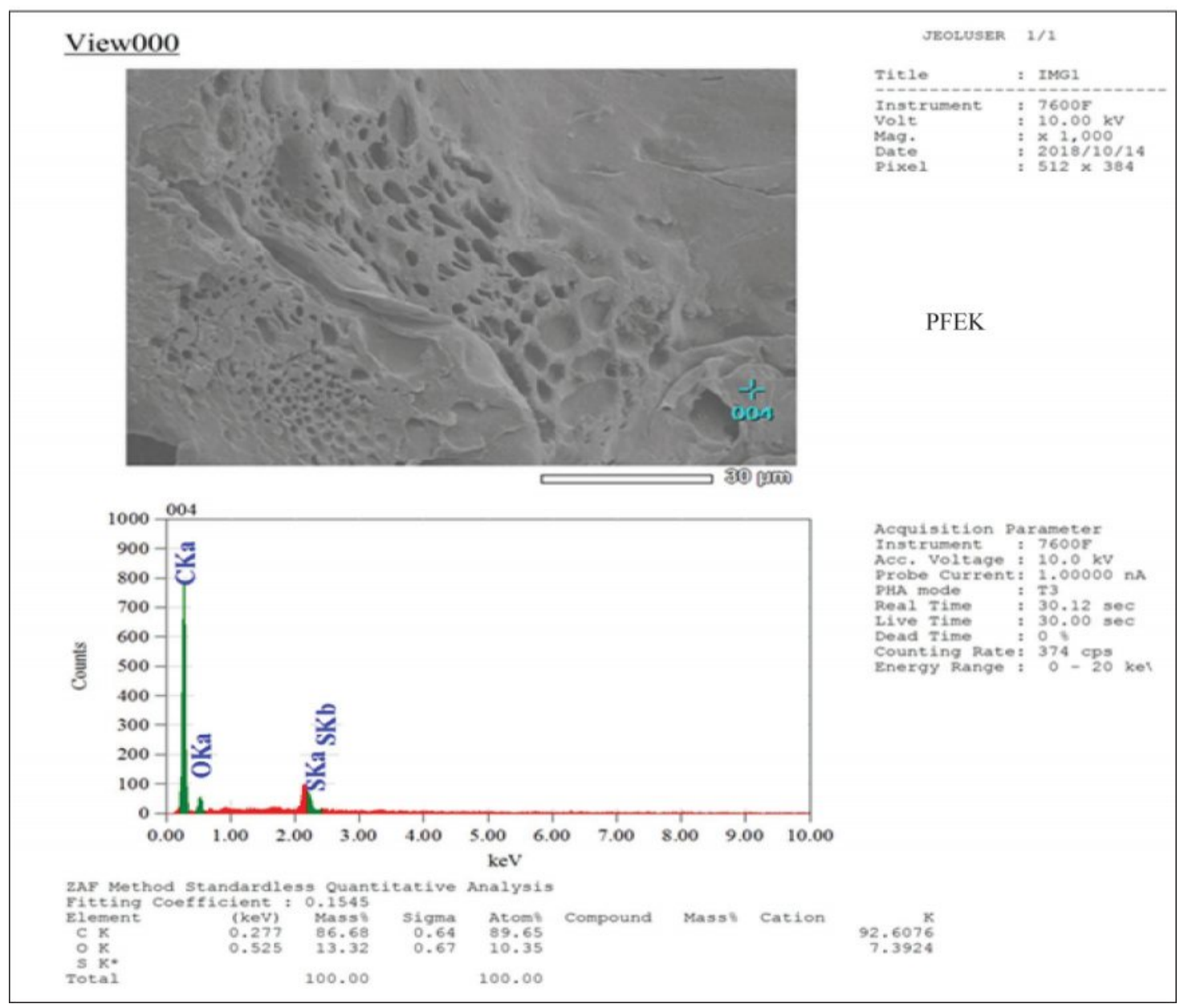

Fig. 6. EDS data of synthesized poly (fluorenylene ether ketone) containing bisphenol A moiety, (PFEK) 
The surface morphology of the poly(fluorenylene ether ketone) containing bisphenol A moiety, (PFEK) was assessed by field emission scanning electron microscope (FESEM) (Fig. 4). The SEM data displayed the cross linked networkin the polymer with continuous phase that concluded the proper arrangement of the polymer chain as well as the formation of random polymers (Kasoju 2014; Tong et al., 2014). It is predicted that cross linked polymer are able to make good ionic channel to improve the conductivity of proton exchange membrane.

The polymer film was prepared by casting polymer solution to $40 \sim 50 \mu \mathrm{m}$ thickness on a flat glass plate (Tanaka et al., 2010; Tanaka et al., 2011). The thickness of the polymer film was controlled by using polymer wt $\%$ solution (Fig. 5). The film looks robust that proves highly viscous fibrous polymer solution.

We have also examined the presence of the monomers in the polymer structure. The EDS data of PFEK, showed the existence of all the monomers in the co-polymer (Fig. 6). This result confirmed that the polymer was prepared successfully.

\section{Conclusions}

This paper represents some developments in polymer preparation. Random polymers have been prepared through condensation polymerization by modification of chemical structure to improve the functional group insertion. The polymers' yield satisfied the required level. ${ }^{1} \mathrm{H}$ NMR results were in good agreement with the polymer structure. The surface morphology was studied by FESEM that showed the good linkage among the polymer chains. Viscosity of the polymers provides good information on polymer's molecular weight. Inherent viscosities of the polymers were investigated. The obtained results support the rationally good molecular weight. Finally, this research demonstrates the preparation of promising polymers with different structural moieties as excellent polymer electrolyte membrane's material.

\section{Acknowledgement}

The authors are very much grateful to University Grants Commission (UGC), Bangladesh, for its generous financial support to make this research work successful.

\section{References}

Carretta N, Tricoli V, Picchioni F (2000), Ionomeric membranes based on partially sulfonated poly(styrene): synthesis, proton conduction and methanol permeation, J. Membr. Sci.166: 189-197.

Ding J, Chuy C, Holdcroft S (2001), A Self-organized Network of Nanochannels Enhances Ion Conductivity through Polymer Films, Chem. Mater. 13: 2231-2233.

Hagberg EC, Olson DA, Sheares VV (2004), Advances in Ni(0)-Catalyzed Coupling for the Synthesis of Polythiophenes and Polyphenylenes, Macromolecules 37: 4748-4754.

Hubner G, Roduner E (1999), EPR investigation of HO radical initiated degradation reactions of sulfonated aromatics as model compounds for fuel cell proton conducting membranes, J. Mater. Chem. 9: 409-418.

Jones DJ, Roziere J (2001), Recent Advances in the Functionalization of Polybenzimidazole and Polyetherketone for Fuel Cell Applications, J. Membr. Sci. 185: 41-58.

Kasoju N (2014), Dip TIPS as a Facile and Versatile Method for Fabrication of Polymer Foams with Controlled Shape, Size and Pore Architecture for Bioengineering Applications, PLOS ONE 9: 1-16.

Kobayashi T, Rikukawa M, Sanui K, Ogata N (1998), Proton-conducting polymers derived from poly (ether-etherketone) and poly (4-phenoxybenzoyl-1, 4-phenylene), Solid State Ionics 106: 219-225.

Kreuer KD (2001), On the development of proton conducting polymer membranes for hydrogen and methanol fuel cells, J. Membr. Sci. 185: 29-39.

Mauritz KA, Moore RB (2004), State of understanding of Nafion, Chem. Rev. 104: 4535-4585.
Nakabayashi
$\mathrm{K}$
K, Matsumoto K, Higashihara T, Ueda M (2008), Influence of adjusted hydrophilic-hydrophobic lengths in sulfonated multiblockcopoly (ether sulfone) membranes for fuel cell application, J. Polym. Sci. Part A: Polym. Chem. 46: $7332-7341$. 
Nakabayashi K, Higashihara T and Ueda M (2010), Highly sulfonated multiblockcopoly (ether sulfone)s for fuel cell membranes, J. Polym. Sci. Part A: Polym. Chem. 48: $2757-2764$.

Nakabayashi K, Matsumoto K and Ueda M (2008), Synthesis and properties of sulfonated multiblockcopoly (ether sulfone)s by a chain extender, J. Polym. Sci. Part A: Polym. Chem. 46: 3947-3957.

Nolte R, Ledjeff K, Bauer M, Mülhaupt R (1993), Partially sulfonated poly(arylene ether sulfone) - A versatile proton conducting membrane material for modern energy conversion technologies, J. Membr. Sci. 83: 211-220.

Pan J, Lu S, Li Y, Huang A, Zhuang L, Lu J (2010), High-performance alkaline polymer electrolyte for fuel cell applications, Adv. Funct. Mater. 20: 312-319.

Roy A, Hickner MA, Einsla BR, Harrison WL, J. E. McGrath JE (2009), Synthesis and characterization of partially disulfonated hydroquinone-based poly(arylene ether sulfone)s random copolymers for application as proton exchange membranes, J. Polym. Sci. Part A: Polym. Chem. 47: 384-391.

Roziere J, Jones DJ (2003), Non-Fluorinated Polymer Materials for Proton Exchange Membrane Fuel Cells, Annu. Rev. Mater. Res. 33: 503-555.

Savadogo OJ (1998), Emerging membranes for electrochemical systems: (I) solid polymer electrolyte membranes for fuel cell systems, New Mater.Electrochem. Syst.1: 47-66.

Singh R, Hay AS (1992), Synthesis and physical properties of soluble, amorphous poly(ether ketone)s containing the o-dibenzoylbenzene moiety, Macromolecules 25: 1017-1024
Tanaka M, Fukasawa K, Nishino E, Yamaguchi S, Yamada K, Tanaka H, Bae B, Miyatake K, Watanabe M (2011), Anion conductive block poly(arylene ether)s: synthesis, properties, and application in alkaline fuel cells, J. Am.Chem. Soc.133: 10646-10654.

Tanaka M, Koike M, Miyatake K, Watanabe M (2010), Anion conductive aromatic ionomers containing fluorenyl groups, Macromolecules 43: 2657-2659.

Tong X, Wang Q, Wang H, Li X, Wu W, Che X (2014), Fabrication of $\mathrm{pH}$ sensitive amphiphilic hot-melt pressure sensitive adhesives for transdermal drug delivery system, Int. J. Adhes. Adhes.48: 217-223.

Wang F, Hickner M, Kim YS, Zawodzinski TA, McGrath JE (2002).Direct polymerization of sulfonated poly(arylene ether sulfone) random (statistical) copolymers: candidates for new proton exchange membranes, J. Membr. Sci. 197: 231-242.

Wang J, Wang J, Zhang S (2012), Synthesis and characterization of cross-linked poly(arylene ether ketone) containing pendant quaternary ammonium groups for anion-exchange membranes, J. Membr. Sci. 415-416: 205-212.

Zaidi SMJ, Mikhailenko SD, Robertson GP, Guiver MD, Kaliaguine S (2000), Proton conducting composite membranes from polyether ether ketone and heteropolyacids for fuel cell applications, J. Membr. Sci. 173: 17-34.

Zhou J, Murat Unlu M, Jose A. Vega JA, Paul A. Kohl PA (2009), Anionic polysulfone ionomers and membranes containing fluorenyl groups for anionic fuel cells, $J$. Power Sources 190: 285-292. 